\title{
In silico molecular docking and ADME/T analysis of plant compounds against IL17A and IL18 targets in gouty arthritis
}

\author{
Sowmya Hari* \\ Department of Bio-Engineering, School of Engineering, Vels Institute of Science, Technology and Advanced Studies (VISTAS), Chennai, India.
}

\begin{tabular}{l}
\hline ARTICLE INFO \\
\hline Received on: 23/12/2018 \\
Accepted on: 20/05/2019 \\
Available online: 01/07/2019 \\
\\
Key words: \\
Gout, IL17A, IL18, in silico, \\
AutoDock, ADME/T.
\end{tabular}

\section{ARTICLE INFO}

eceived on: 23/12/2018

Accepted on: 20/05/2019

Key words:

AutoDock, ADME/T.

\begin{abstract}
Accumulation of urate crystals and subsequent inflammation are the major cause of pathogenesis of gout. Two pro inflammatory cytokines IL17A and IL18 are upregulated in the serum of gout patients and plays a major role in promoting inflammation. Inhibition of these cytokines by plant phytochemicals would reduce the severity of inflammation in gout. In the present study, in silico analysis of inhibition of IL17A and IL18 by 10 plant phytochemicals were studied using the AutoDock 4.2 based on the principles of Lamarckian genetic algorithm. The results revealed a binding energy in the range of $-6.32 \mathrm{kcal} / \mathrm{mol}$ to $-3.5 \mathrm{kcal} / \mathrm{mol}$ and interacted with the amino acids in active pocket of IL17A and IL18. Among all the compounds, syringaresinol showing the least binding energy of $-6.05 \mathrm{kcal} / \mathrm{mol}$ with IL17A and $-6.32 \mathrm{kcal} / \mathrm{mol}$ with IL18. The control drug, allopurinol showed a binding energy of -3.32 and -3.18 $\mathrm{kcal} / \mathrm{mol}$ with IL17A and IL18, respectively. In addition, ADME/T properties of the compounds were also analyzed to predict their drug likeliness. This docking study can be used for developing potent inhibitors of IL17A and IL18 for the treatment of gout.
\end{abstract}

\section{INTRODUCTION}

Gout is a common chronic arthritis with every $9.5 \%$ to $13.5 \%$ per 1,000 persons getting affected (Saigal et al., 2015). The pathophysiology of the disease is mainly due to the improper uric acid metabolism leading to the precipitation and accumulation of uric acid crystals in joints, bones, tissues, and many other organs. Hence, gout is also known as hyperuricemia (Ragab et al., 2017). Gout is more common in male compared to female with a ratio of $4: 1$. However, the incidence increases in women after menopause (Doherty, 2009). In addition to inflammation in joints, bones persons with gout are at the risk of developing chronic kidney disease, hypertension, cardiovascular diseases, metabolic disorders, and psychosis (Chiu et al., 2012; Feig et al., 2008; Gerald and Falasca, 2006; Grayson et al., 2011; Mohandas and Johnson, 2008; Soltani et al., 2013).

"Corresponding Author

Sowmya Hari, Department of Bio-Engineering, School of Engineering, Vels Institute of Science, Technology and Advanced Studies (VISTAS), Chennai, India.E-mail: sowmya.se@velsuniv.ac.in
Hypoxanthine and xanthine formed during purine metabolism are metabolized in the liver to uric acid by the enzyme xanthine oxidase (Kostalova et al., 2015). Uricase, an enzyme that degrades the uric acid to soluble allantoin but humans lack this enzyme. Hence, uric acid is not degraded leading to the accumulation of insoluble uric acid crystals in joints, bones, and many other organs like kidney (El Ridi and Tallima, 2017; Roddy and Doherty, 2010). Xanthine oxidase is the primary target to inhibit uric acid formation and in the treatment of Gout. Other main biomarkers in gout are interleukin (IL) 17A and IL18, proinflammatory cytokines that are upregulated in the serum of gout patients (Cavalcanti et al., 2016; Liu et al., 2018). These cytokines are also targets in many other diseases; IL17A is the major target in many other diseases, such as psoriasis, rheumatoid arthritis, systemic lupus erythematosus, and also in many different cancers (Kirkham et al., 2014). IL18 is mainly involved in many autoimmune diseases (Sedimbi et al., 2013).

In gout patients, IL17A binds to its receptor leading to chemokine release (Zhou et al., 2016). Monoclonal antibody, secukinumab is the only one approved IL-17A inhibitor at present (Frieder et al., 2018). Drugs to treat IL18, another major proinflammatory cytokine upregulated in gout are currently under 
investigation. Targetting these cytokines with chemical drug can be effective, however, may lead to many side effects. Hence, identification of plant-based compounds with IL17A and IL18 inhibitory potential can be an important breakthrough in the treatment of Gout. This is the first In silico study to find the binding potential of plant-based medicinal compounds to proinflammatory cytokines IL17A and IL18, important biomarkers in gout. The results from this study can be a foundation for developing new drugs for Gout treatment.

\section{MATERIALS AND METHODS}

\section{Macromolecules structure retrieval}

The structure of IL17A-PDB ID:4HR9 and IL18-PDB ID: 3WO2 were retrieved from Protein Data Bank (PDB) (Huang et al., 2015). PDB is a database that contains the data of experimental structures of proteins and nucleic acids. Structure of IL7A was a homodimer (chain A and B) and IL18 3WO2 was homotetramer (chain A, B, C, and D). Only chain A was used for docking studies. Other chains and water molecules were removed using PyMol (Fig. 1). PyMol is a useful open source software tools to perform molecular graphics (Yuan et al., 2017)

\section{Ligand structure retrieval}

Eleven plant-based molecules: carvacrol, thymol, thiamine, riboflavin, limonene, diadzein, genistein, canthin-6-one, syriacusin A, syringaresinol, and gossypin with potential pharmaceutical and medicinal benefits were chosen for the ligand protein docking study. The docking study was performed against a control drug Allopurinol, prescribed to gout patients to reduce gout attacks. The structures of the ligand molecules and the control drug Allopurinol were retrieved from Pubchem database. Pubchem contains information about chemical compounds their structure, molecular formula, molecular weight, etc. (Kim et al., 2015). The structures were retrieved in SDF format and were changed to PDB format using PyMol. The structure and medicinal properties of the ligands are listed in Table 1.

\section{Drug scan}

All the ligands were tested for their drug potential based on Lipinski's rule of five. Molinspiration (http://www. molinspiration.com/cgi-bin/properties) was used for calculating Lipinski's properties. Lipinski's rule mainly determine the molecular attributes, such as molecular weight, $\log \mathrm{P}$, number of hydrogen bond acceptors, and number of hydrogen bond donors. Any ligand showing violations in Lipinski's rule were eliminated from further studies (Lipinski et al., 2012).

\section{Active site prediction}

Amino acids involved in active pocket formation were determined using Computed Atlas for Surface Topography of proteins (CASTp). CASTp is a very easy and useful web-based tool for determining the topology and active site pockets in the proteins (Dundas et al., 2006). Active site determination is important to set the grid box at before docking.

\section{Docking and visualization}

AutoDock 4.2 was used for docking of ligands to the proteins. AutoDock is the fully automated docking software tool most widely used to study the protein ligand binding and interactions (Morris et al., 2009). Protein molecule was initially fixed by adding polar hydrogen, kollman charges (Azam and Abbasi, 2013). Ligand molecule was added with gasteiger charges (Karunakar et al., 2014). Autodock 4.2 allows setting a specific target site with the help of grid box. The $\mathrm{X}, \mathrm{Y}$, and $\mathrm{Z}$ dimensions were set to $40 * 40 * 40$, the $X$ center, $Y$ center, and $Z$ center were adjusted based on the active site of the proteins (Adejoro et al., 2016). The output for ligand conformations were analyzed using stochastic Lamarckian genetic algorithm (Morris et al., 1998). The least negative $\Delta G$ indicates a strong binding and favorable conformation for the ligand and the protein interaction (Afriza et al., 2018). The 3D visualization of docked structures was performed using graphical user interface, Discovery studio (Kemmish et al., 2017). Protein-ligand interactions, structure and ligand designing are few facilities available in Discovery studio (Meenambiga et al., 2018)

\section{ADME/T prediction}

Absorption, distribution, metabolism, excretion, and toxicity (ADMET) of the ligands are their pharmacokinetic properties and are needed to be evaluated to determine their activity inside the body. The ADMET properties of the ligands were analyzed using admetSAR, an online ADMET prediction tool (http://lmmd.ecust.edu.cn:8000/) (Cheng et al., 2012).

\section{RESULTS AND DISCUSSION}

Globally, Gout incidence and prevalence is continuously increasing with people aged above 30 years which is getting greatly affected. In addition to joint pains, Gout is also associated with organ failure due to the accumulation of uric acid crystals in the organs. Serum levels of proinflammatory cytokines IL17a and IL18 are upregulated in Gout patients, leading to inflammation and pain. Many plant-based herbal solutions are used for gout treatments for many decades. In this study, 11 plant compounds with potential medicinal and pharmaceutical potential were chosen for their ability to inhibit IL17A and IL 18. The structure of these ligands was obtained from pubchem (Table 1). The structure of IL17a and IL18 were retrieved from PDB. Any extra chains and water molecules were removed from the proteins using PyMol and the resulting protein file was saved as PDB file (Fig. 1).

For in silico analysis of plant compounds, the drug potential of all the ligands was tested using Lipinski's rule of five. Molinspiration server was used to analyze the molecular parameters of the ligands in the Lipinski's rule. The results include the molecular weight, no of hydrogen donors, acceptors, and lipophilicity of the ligand molecules. Out of the 11

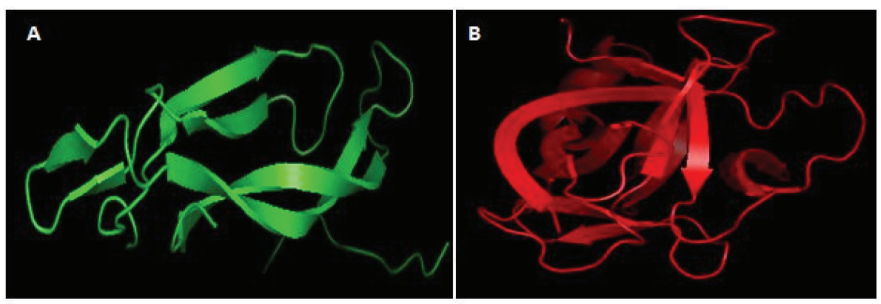

Figure 1. Chain-A Structure of A) IL17A and B) IL18 viewed using PyMol. 
Table 1. Structure and medicinal uses of plant phytochemicals.

\begin{tabular}{|c|c|c|c|c|c|}
\hline S. no & Compound & Molecular formula & Molecular structure & Medicinal properties & References \\
\hline 1 & Canthin-6-one & $\mathrm{C}_{14} \mathrm{H}_{8} \mathrm{~N}_{2} \mathrm{O}$ & & $\begin{array}{l}\text { Antitumor, antibacterial, antifungal, } \\
\text { antiparasitic, anti-inflammatory }\end{array}$ & (Dai et al.,2015) \\
\hline 2 & Carvacrol & $\mathrm{C}_{10} \mathrm{H}_{14} \mathrm{O}$ & & $\begin{array}{l}\text { Antibacterial, antifungal, } \\
\text { insecticidal, and anti-oxidative }\end{array}$ & (Naghdi Badi et al., 2017) \\
\hline 3 & Diadzein & $\mathrm{C}_{15} \mathrm{H}_{10} \mathrm{O}_{4}$ & & $\begin{array}{l}\text { Anti-inflammation, } \\
\text { anticancer,inhibition of oxidative } \\
\text { damage, protection of skin and the } \\
\text { nerve }\end{array}$ & (Sun et al., 2016) \\
\hline 4 & Genistein & $\mathrm{C}_{15} \mathrm{H}_{10} \mathrm{O}_{5}$ & & Anti inflammatory & (Verdrengh et al., 2003) \\
\hline 5 & Gossypin & $\mathrm{C}_{21} \mathrm{H}_{20} \mathrm{O}_{13}$ & & $\begin{array}{l}\text { antioxidant, anti-inflammatory, } \\
\text { anticonvulsant and anti-cancer } \\
\text { activities }\end{array}$ & (Chandrashekhar et al., 2013) \\
\hline 6 & Limonene & $\mathrm{C}_{10} \mathrm{H}_{16}$ & & Antioxidant, neuroprotective & $\begin{array}{l}\text { (Marashly and Bohlega, } \\
\text { 2017) }\end{array}$ \\
\hline 7 & Riboflavin & $\mathrm{C}_{17} \mathrm{H}_{20} \mathrm{~N}_{4} \mathrm{O}_{6}$ & & Anti inflammatory, neuroprotective & $\begin{array}{l}\text { (Marashly and Bohlega, } \\
\text { 2017) }\end{array}$ \\
\hline 8 & Syriacusin A & $\mathrm{C}_{13} \mathrm{H}_{12} \mathrm{O}_{4}$ & & $\begin{array}{l}\text { Anti ageing, prevents oxidative } \\
\text { stress }\end{array}$ & (Shi et al., 2014) \\
\hline 9 & Syringaresinol & $\mathrm{C}_{22} \mathrm{H}_{26} \mathrm{O}_{8}$ & & $\begin{array}{l}\text { Prevents oxidative damage, } \\
\text { anti inflammatory }\end{array}$ & (Chung et al., 2012) \\
\hline 10 & Thiamine & $\mathrm{C}_{12} \mathrm{H}_{17} \mathrm{~N}_{4} \mathrm{OS}^{+}$ & & $\begin{array}{l}\text { Improves immunity, } \\
\text { anti inflammatory, } \\
\text { prevents oxidative stress }\end{array}$ & (de Andrade et al., 2014) \\
\hline 11 & Thymol & $\mathrm{C}_{10} \mathrm{H}_{14} \mathrm{O}$ & & $\begin{array}{l}\text { Antibacterial, antifungal, } \\
\text { insecticidal, and anti-oxidative }\end{array}$ & (Naghdi Badi et al., 2017) \\
\hline
\end{tabular}


compounds studied, 10 compounds cleared Lipinski's rule of five, except gossypin, which showed two violations; hence, the compound was eliminated from further docking analysis. Log $p$ value indicates the hydrophilic and hydrophobic nature of the ligands. Only thiamine, riboflavin had negative $\log p$ score indicating that these compounds are highly hydrophilic in nature (Table 2).

Active site pockets in IL17A and IL18 were determined using CASTp. CASTp is a web-based tool to determine the amino acid residues in the active pocket of the proteins. CASTp results are depicted in Figure 2 for IL17A and Figure 3 for IL18.

Table 2. Lipinski properties of plant compounds analyzed using molinspiration.

\begin{tabular}{|c|c|c|c|c|c|c|}
\hline S. No & Compound & Molecular weight ( $<500$ Da) & $\log \mathrm{P}(<5)$ & H-bond donor (5) & H-bond acceptor $(<10)$ & No. of violations \\
\hline 1 & Allopurinol & 136.11 & -0.53 & 2 & 5 & 0 \\
\hline 2 & Canthin-6-one & 220.23 & 2.69 & 0 & 3 & 0 \\
\hline 3 & Carvacrol & 150.22 & 3.81 & 1 & 1 & 0 \\
\hline 4 & Diadzein & 254.24 & 2.56 & 2 & 4 & 0 \\
\hline 5 & Genistein & 270.24 & 2.27 & 3 & 5 & 0 \\
\hline 6 & Gossypin & 480.38 & -0.62 & 9 & 13 & 2 \\
\hline 7 & Limonene & 136.24 & 3.62 & 0 & 0 & 0 \\
\hline 8 & Riboflavin & 376.37 & -0.76 & 5 & 10 & 0 \\
\hline 9 & Syriacusin A & 232.24 & 2.94 & 2 & 4 & 0 \\
\hline 10 & Syringaresinol & 418.44 & 2.62 & 2 & 8 & 0 \\
\hline 11 & Thiamine & 265.36 & -3.45 & 3 & 5 & 0 \\
\hline 12 & Thymol & 150.22 & 3.34 & 1 & 1 & 0 \\
\hline
\end{tabular}

Chain A

PRTVMVNLNIHYYDRSTSPWNLHRNEDPERYPSVIWEAKCRHLGCINADGNV
DYHMNSVPIQQEILVLRREPPHSPNSFRLEKILVSVGCTCVTPI

Figure 2. Results of amino acids involved in forming active site for IL17A. Letters highlighted in blue indicates active site residues.

Chain A

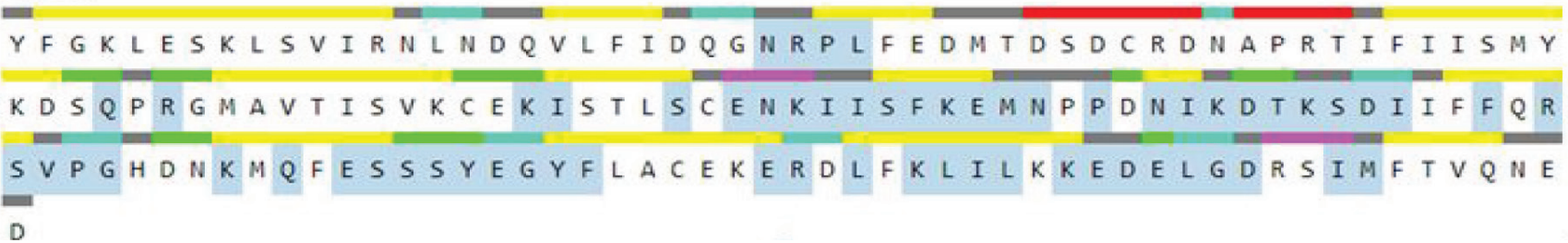

Figure 3. Results of amino acids involved in forming active site for IL18. Letters highlighted in blue indicates active site residues.

Table 3. List of amino acids in the active site pocket of IL17A obtained from CASTp.

\begin{tabular}{lccc}
\hline Amino acid & Position & Amino acid & Position \\
\hline Leucine & 53 & Isoleucine & 96 \\
Tyrosine & 62 & Leucine & 97 \\
Proline & 63 & Valine & 98 \\
Valine & 65 & Leucine & 99 \\
Isoleuine & 66 & Leucine & 112 \\
Tryptophan & 67 & Lysine & 114 \\
Alanine & 69 & Valine & 117 \\
Glutamine & 94 & Serine & 118 \\
Glutamic acid & 95 & Valine & 119 \\
\hline
\end{tabular}


Table 4. List of amino acids in the active site pocket of IL18 obtained from CASTp.

\begin{tabular}{|c|c|c|c|}
\hline Amino acid & Position & Amino acid & Position \\
\hline Aspargine & 26 & Serine & 105 \\
\hline Arginine & 27 & Valine & 106 \\
\hline Proline & 28 & Proline & 107 \\
\hline Leucine & 29 & Glycine & 108 \\
\hline Glutamine & 56 & Lysine & 112 \\
\hline Arginine & 58 & Glutamine & 114 \\
\hline Lysine & 70 & Glutamine & 116 \\
\hline Isoleucine & 71 & Serine & 117 \\
\hline Serine & 75 & Serine & 118 \\
\hline Glutamic acid & 77 & Serine & 119 \\
\hline Aspargine & 78 & Tyronisine & 120 \\
\hline Lysine & 79 & Glutamic acid & 121 \\
\hline Isoleucine & 80 & Glycine & 122 \\
\hline Isoleucine & 81 & Tyrosine & 123 \\
\hline Serine & 82 & Phenylalanine & 124 \\
\hline Phenylalanine & 83 & Glutamic acid & 130 \\
\hline Lysine & 84 & Arginine & 131 \\
\hline Glutamic acid & 85 & Leucine & 133 \\
\hline Methionine & 86 & Lysine & 135 \\
\hline Aspargine & 87 & Leucine & 136 \\
\hline Proline & 89 & Isoleucine & 137 \\
\hline Aspargine & 91 & Leucine & 138 \\
\hline Isoleucine & 92 & Lysine & 140 \\
\hline Lysine & 93 & Glutamic acid & 141 \\
\hline Aspartic acid & 94 & Aspartic acid & 142 \\
\hline Threonine & 95 & Glutamic acid & 143 \\
\hline Lysine & 96 & Leucine & 144 \\
\hline Serine & 97 & Glycine & 145 \\
\hline Aspartic acid & 98 & Aspartic acid & 146 \\
\hline Isoleucine & 99 & Isoleucine & 149 \\
\hline Phenylalanine & 102 & Methionine & 150 \\
\hline Arginine & 104 & & \\
\hline
\end{tabular}

From CASTp results, only the amino acids in the active site and their positions are listed as Table 3 for IL17A and Table 4 for IL18. Autodock4.2 was used for performing docking analysis for all the 10 compounds and their binding potential with both IL17a and IL18 was analyzed. Autodock4.2 is used to analyze the affinity, binding conformations, best orientation of ligand and target (Morris et al., 2009). The binding energy, number of hydrogen bond interactions, and amino acids involved in the interactions are tabulated in Table 5 for IL17A and Table 6 for IL18.

The docking studies of the compounds with IL17A revealed that syringaresinol a polyphenolic ligand showed the lowest binding energy of $-6.05 \mathrm{kcal} / \mathrm{mol}$. With IL17A, syringaresinol formed four hydrogen bonds with Ala69, Glu68, Cys71, and Ser118 (Fig. 4A). The anti-inflammatory potential of syringaresinol was also proved by their inhibition of iNOS, COX-2, TNF- $\alpha$, IL-1 $\beta$, and IL-6 by in vitro studies (Bajpai et al., 2018). Diadzein, an isoflavone and a potential inhibitor of TNF- $\alpha$ (Soumyakrishnan et al., 2011), showed a good binding energy of $-5.23 \mathrm{kcal} / \mathrm{mol}$ and formed hydrogen bonds with GLU68, SER89, CYS71 with IL17A (Fig. 4B). Canthin-6-one also proved to inhibit TNF- $\alpha$ and monocyte chemoattractant protein from in vitro studies (Cho et al., 2018). In this study, canthin-6-one, showed a binding affinity of $-5.06 \mathrm{kcal} / \mathrm{mol}$ with the protein IL17A (Fig. 4C). With IL17A compounds Syriacusin A, Riboflavin, Genistein, and Thiamine showed a binding energy in the range of $-4.96 \mathrm{kcal} / \mathrm{mol}$ and $-4.1 \mathrm{kcal} / \mathrm{mol}$. The ligands and their docking interactions with IL17A amino acids are shown in Figure 4D-G, respectively. Thymol and its isomer carvacrol are proved for their inhibitory actions against IL1 $\beta$ and TNF- $\alpha$ (Gholijani et al., 2014). In this study, docking of Thymol and Carvacrol with IL17A showed binding energies in the same range with values $-3.70 \mathrm{kcal} / \mathrm{mol}$ and $-3.75 \mathrm{kcal} / \mathrm{mol}$, respectively. Figure $4 \mathrm{H}$ and I show the interactions of thymol and carvacrol with IL17A. All the compounds used in the study showed a binding energy greater than the standard drug Allopurinol, that showed a binding energy of $-3.32 \mathrm{kcal} / \mathrm{mol}$ with IL17A (Fig. 4J)

With IL18 again syringaresinol showed the least binding energy of $-6.32 \mathrm{kcal} / \mathrm{mol}$ and formed one hydrogen bond with Ser 118, in the active site of the protein (Fig. 5A). Docking of Diadzein with IL18 showed a binding energy of $-5.6 \mathrm{kcal} / \mathrm{mol}$ forming hydrogen bonds at ARG 104, SER118 (Fig. 5B). Canthin6-one, showed a binding affinity of $-5.15 \mathrm{kcal} / \mathrm{mol}$ with IL18 (Fig. 5C). Syriacusin A, Riboflavin, Genistein, and Thiamine showed a binding energy in the range between -5.14 and -3.75 $\mathrm{kcal} / \mathrm{mol}$ with IL18. Figure $5 \mathrm{D}-\mathrm{G}$ depicts the association of these compounds with IL18, respectively. With IL18, thymol and carvacrol gave a binding energy of $-3.56 \mathrm{kcal} / \mathrm{mol}$ and $-3.51 \mathrm{kcal} /$ mol. Figure $5 \mathrm{H}$ and I show thymol and carvacrol interactions with IL18. Allopurinol showed a binding energy of $-3.18 \mathrm{kcal} / \mathrm{mol}$ with IL18 (Fig. 5J).

All the compounds except limonene formed bonds with the amino acids in the active site pockets of IL17A and IL18. Though limonene did not form any hydrogen bond with both IL17A and IL18, it formed other interactions with the 4 amino acids in IL17A and 11 amino acids in IL18 protein. The ADMET properties of the ligands are needed to be known for determining their drug likeliness. The ADMET properties of the ligands were analyzed using admetSAR. ADMET properties for the compounds in the study were analyzed using admetSAR. All the compounds showed good human intestinal solubility (HIA), blood brain barrier (BBB) penetration. No drug was carcinogenic. Salmonella typhimurium reverse mutation assay (AMES) toxicity is a preliminary drug screening test to analyze whether the drug causes any mutation in bacteria Salmonella typhimurium. All the compounds except Canthin-6-one and Syriacusin A were AMES negative. The lethal dose (LD50) in rats was also analyzed. The results of HIA, BB penetration, LD50 values for the compounds are listed in Table 7. 
Table 5. Molecular docking analysis of plant compounds with IL17A.

\begin{tabular}{|c|c|c|c|c|c|c|}
\hline S. no & Compound & $\begin{array}{l}\text { Binding Affinity } \\
\text { kcal } / \mathrm{mol}\end{array}$ & $\begin{array}{l}\text { No of } \mathbf{H} \\
\text { Bonds }\end{array}$ & $\mathrm{H}$ bonds interaction residues & Other interaction residues & $\begin{array}{c}\text { No. of direct contacts } \\
\text { (polar and non-polar interactions) }\end{array}$ \\
\hline 1 & Allopurinol & -3.32 & 1 & TRP 67 & $\begin{array}{l}\text { ILE 66, VAL 65, ILE 66, PRO 63, } \\
\text { ILE } 96\end{array}$ & 6 \\
\hline 2 & Canthin-6-one & -5.06 & 2 & SER 118, LEU 116 & $\begin{array}{l}\text { CYS 71, LYS 70, PRO 91, ALA } \\
69, \text { GLU 68, GLN 93, VAL } 117\end{array}$ & 9 \\
\hline 3 & Carvacrol & -3.75 & 2 & ALA 69, SER 118 & $\begin{array}{l}\text { CYS 71, PRO 91, SER 89, } \\
\text { LYS 70, }\end{array}$ & 6 \\
\hline 4 & Diadzein & -5.23 & 3 & GLU 68, SER 89, CYS 71 & $\begin{array}{l}\text { ALA 69, LYS 70, VAL 90, } \\
\text { PRO 91, GLN 93, SER 118, }\end{array}$ & 9 \\
\hline 5 & Genistein & -4.76 & 4 & GLU 68, ALA 69, CYS 71, SER 118 & $\begin{array}{l}\text { CYS 121, PRO 91, LYS } 70, \\
\text { ASN 56, LEU 116, GLN } 93\end{array}$ & 10 \\
\hline 6 & Limonene & -3.54 & 1 & CYS 71 & $\begin{array}{l}\text { HIS 73, LEU 74, SER } 89, \\
\text { PRO 91 }\end{array}$ & 5 \\
\hline 7 & Riboflavin & -4.55 & 3 & ALA 69, LEU 116, GLU 68 & $\begin{array}{l}\text { PRO 91, LYS 70, ASN 56, ARG } \\
61 \text {, ILE 116, VAL 117, SER 118, } \\
\text { GLN } 93\end{array}$ & 11 \\
\hline 8 & Syriacusin A & -4.96 & 2 & SER118, CYS71, VAL 117 & $\begin{array}{l}\text { GLU 68, ALA 69, LYS 70, PRO } \\
\text { 91, LEU 116, GLN 93, }\end{array}$ & 8 \\
\hline 9 & Syringaresinol & -6.05 & 4 & ALA 69, GLU 68, CYS 71, SER 118 & $\begin{array}{l}\text { ASN 56, LYS 70, PRO 91, } \\
\text { GLN 93, LEU 116, SER 118, }\end{array}$ & 10 \\
\hline 10 & Thiamine & -4.15 & 3 & ALA 69, SER 118, LEU 116 & $\begin{array}{l}\text { CYS 71, PRO 91, GLN 93, VAL } \\
\text { 117, ILE 115, LYS 70, GLU 68, } \\
\text { ASN 56, ARG } 61\end{array}$ & 12 \\
\hline 11 & Thymol & -3.70 & 2 & ALA 69, SER 118 & $\begin{array}{l}\text { LYS 70, CYS 71, PRO 91, } \\
\text { GLN } 93\end{array}$ & 6 \\
\hline
\end{tabular}

Table 6. Molecular docking analysis of plant compounds with IL18.

\begin{tabular}{|c|c|c|c|c|c|c|}
\hline & Compound & $\begin{array}{l}\text { Binding Affinity } \\
\text { kcal } / \mathrm{mol}\end{array}$ & $\begin{array}{c}\text { No of } H \\
\text { Bonds }\end{array}$ & $\mathrm{H}$ bonds interaction residues & Other interaction residues & $\begin{array}{c}\text { No. of direct contacts } \\
\text { (polar and non-polar interactions) }\end{array}$ \\
\hline 1 & Allopurinol & -3.18 & 3 & ARG58, SER 117, SER 118 & $\begin{array}{l}\text { ARG104, PHE 102, GLU 116, } \\
\text { GLU } 121\end{array}$ & 7 \\
\hline 2 & Canthin-6-one & -5.15 & 2 & ARG 104, SER 117 & $\begin{array}{l}\text { ARG 58, PRO 57, PHE 102, GLU 116, } \\
\text { SER 118, GLU 121, TYR } 120\end{array}$ & 9 \\
\hline 3 & Carvacrol & -3.51 & 3 & SER117, SER 118, PHE 102 & $\begin{array}{l}\text { LYS } 96, \text { ARG 104, GLU 116, } \\
\text { SER 119, GLU121, TYR 120, ARG } 58\end{array}$ & 10 \\
\hline 4 & Diadzein & -5.6 & 2 & ARG 104, SER 118 & $\begin{array}{l}\text { ARG } 58 \text {, PHE 102, GLU } 116, \\
\text { SER } 117, \text { LYS } 96, \text { SER } 119, \\
\text { TYR } 120, \text { GLU } 121\end{array}$ & 10 \\
\hline 5 & Genistein & -4.35 & 2 & ARG 104, SER 117 & $\begin{array}{l}\text { PHE 102, GLU 116, TYR 120, GLU } \\
\text { 121, GLY 122, ARG } 58 \text {, GLN } 56\end{array}$ & 9 \\
\hline 6 & Limonene & -3.83 & - & - & $\begin{array}{l}\text { ARG } 58, \text { PRO } 57, \text { GY } 59 \text {, ALA } 61 \text {, } \\
\text { PRO } 88 \text {, ASN } 87 \text {, MET } 51 \text {, TYR } 52 \text {, } \\
\text { LYS } 4 \text {, LYS } 53 \text {, ASP } 54 \text {, }\end{array}$ & 11 \\
\hline 7 & Riboflavin & -5.1 & 3 & GLN 103, MET 60, SER105 & $\begin{array}{l}\text { ASP 104, PRO 57, ARG 58, GLY 59, } \\
\text { ARG 61, ARG } 104\end{array}$ & 9 \\
\hline 8 & Syriacusin A & -5.14 & 2 & GLU 116, SER 118 & $\begin{array}{l}\text { ARG 104, ARG 58, PHE 102, GLN } \\
\text { 56, SER 117, SER 118, THR 95, } \\
\text { LYS 96, GLU } 121\end{array}$ & 11 \\
\hline 9 & Syringaresinol & -6.32 & 1 & SER 118 & $\begin{array}{l}\text { ARG 104, ARG 58, PHE 102, GLU } \\
\text { 116, SER 117, LYS 96, SER 119, } \\
\text { TYR 120, GLU } 121\end{array}$ & 10 \\
\hline 10 & Thiamine & -3.75 & 2 & GLN 56, ARG 104 & $\begin{array}{l}\text { PHE 102, GLU 116, PRO 57, ARG 58, } \\
\text { GLU } 121\end{array}$ & 7 \\
\hline 11 & Thymol & -3.56 & 1 & SER 118 & $\begin{array}{l}\text { ARG 104, ARG 58, GLN 506, PHE } \\
\text { 102, GLU 116, SER 119, LYS 96, } \\
\text { TYR 120, SER 119, GLU } 121\end{array}$ & 11 \\
\hline
\end{tabular}




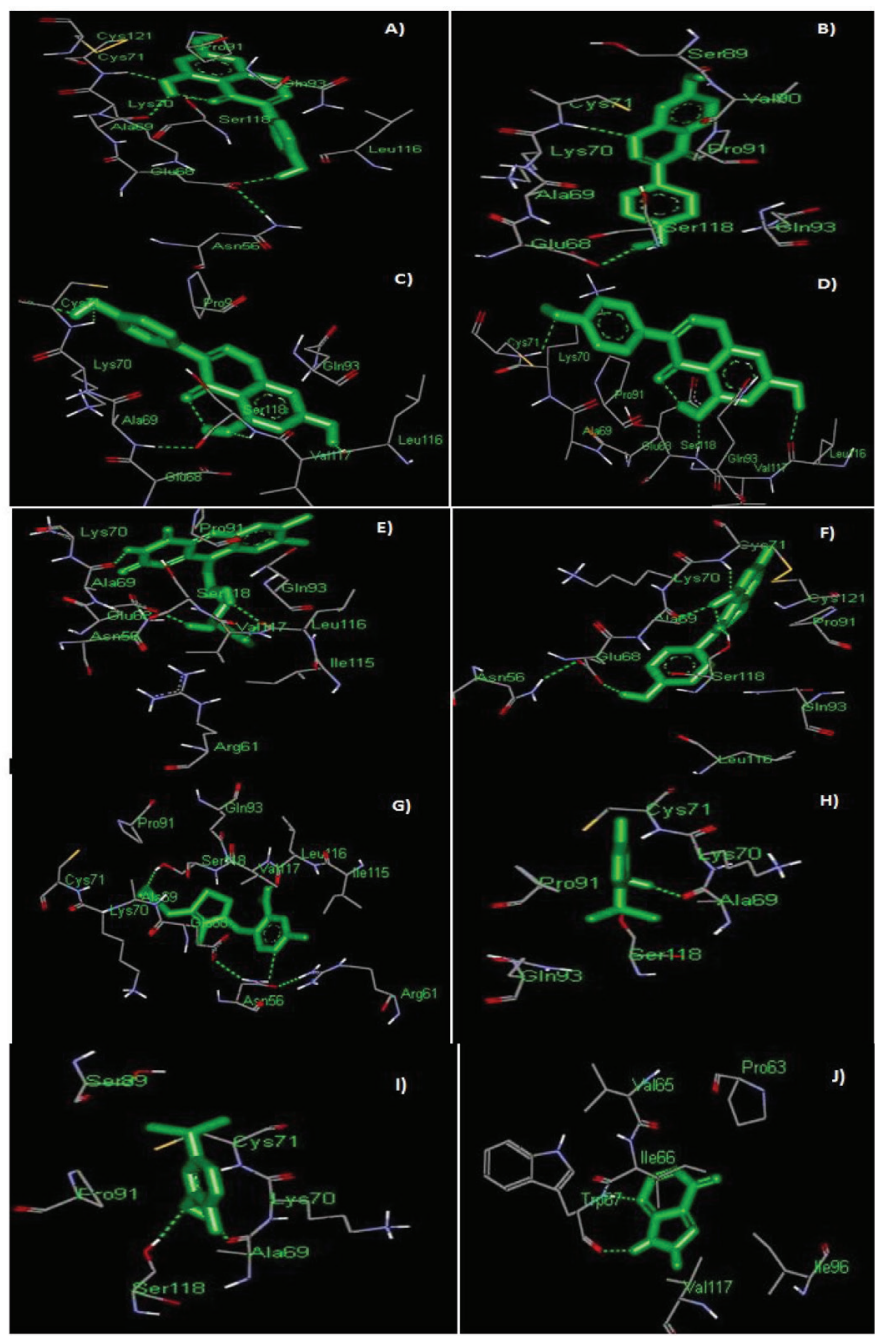

Figure 4. 3D interaction residues of IL17A with (A) Syringaresinol, (B) Diadzein, (C) Canthine 6 one, (D) Syriacusin A, (E) Riboflavin, (F) Genistein, (G) Thiamine, (H) Thymol, (I) Carvacrol, and (J) Allopurinol.

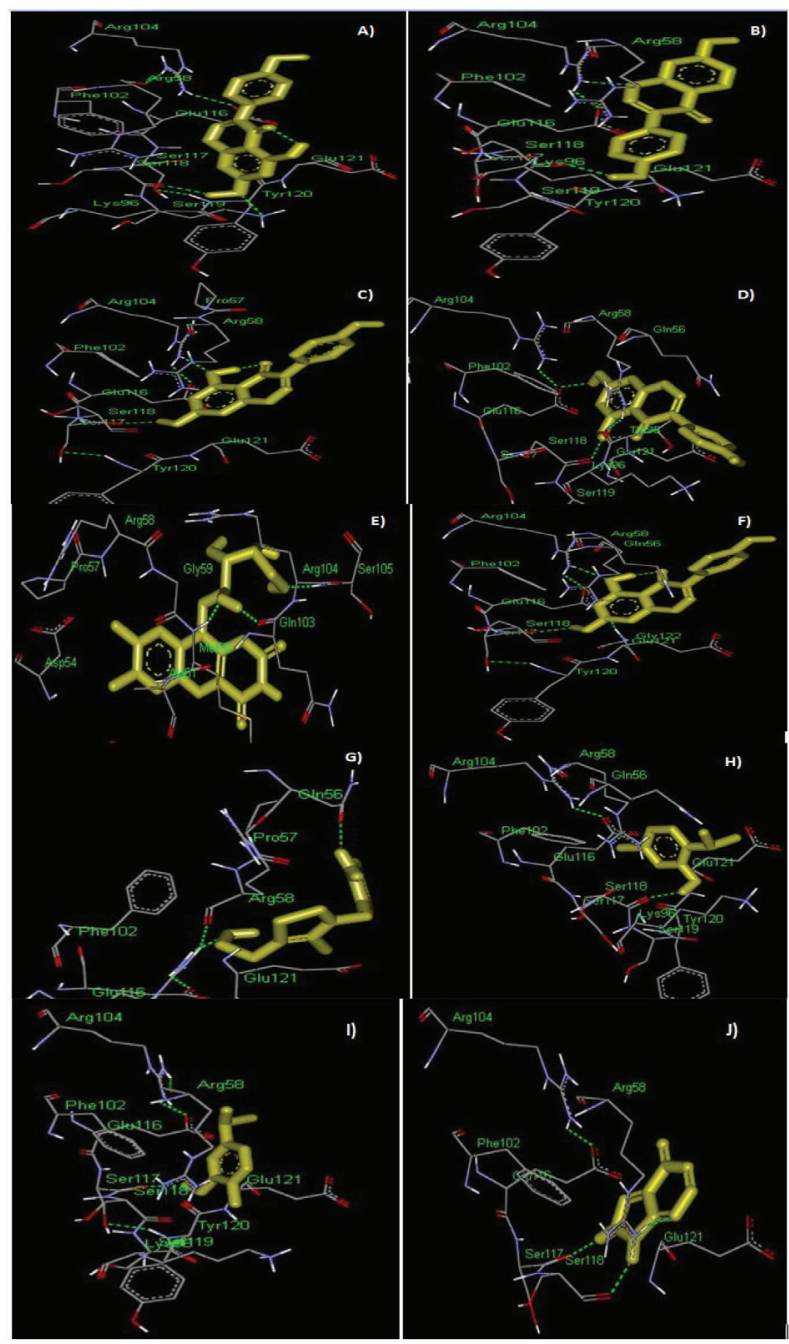

Figure 5. 3D interaction residues of IL18 with (A) Syringaresinol, (B) Diadzein, (C) Canthine 6 one, (D) Syriacusin A, (E) Riboflavin, (F) Genistein, (G) Thiamine, (H) Thymol, (I) Carvacrol, and (J) Allopurinol.

Table 7. ADMET properties of the ligands.

\begin{tabular}{clccllc}
\hline S. no & Compound & HIA & BBB & AMES toxicity & Carcinogenicity & LD50 in rat (mol/kg) \\
\hline 1 & Allopurinol & 0.9770 & 0.9885 & Non-toxic & Non-carcinogen & 2.1087 \\
2 & Canthin-6-one & 0.9928 & 0.9952 & Toxic & Non-carcinogen & 1.8241 \\
3 & Carvacrol & 0.9955 & 0.9381 & Non-toxic & Non-carcinogen & 2.2996 \\
4 & Diadzein & 0.9942 & 0.7448 & Non-toxic & Non-carcinogen & 3.5363 \\
5 & Genistein & 0.9877 & 0.6785 & Non-toxic & Non-carcinogen & 3.2998 \\
6 & Limonene & 0.9887 & 0.9444 & Non-toxic & Non-carcinogen & 1.4819 \\
7 & Riboflavin & 0.9156 & 0.8495 & Non-toxic & Non-carcinogen & 1.6067 \\
8 & Syriacusin A & 0.9900 & 0.5420 & Toxic & Non-carcinogen & 2.6523 \\
9 & Syringaresinol & 0.9944 & 0.5080 & Non-toxic & Non-carcinogen & 2.5946 \\
10 & Thiamine & 0.7976 & 0.9330 & Non-toxic & Non-carcinogen & 2.4577 \\
11 & Thymol & 0.9955 & 0.9381 & Non-toxic & Non-carcinogen & 2.2996 \\
\hline
\end{tabular}

\section{CONCLUSION}

Currently, the drugs available can only prevent gout attacks but does not treat gout. Hence, the identification of new drugs to target and treat gout is of utmost importance. In this study, many drug potential compounds from plants were studied using docking analysis against Gout inflammatory cytokines IL17a and IL18. All the compounds had a good inhibitory potential with both the cytokines. Among them, Syringaresinol, Diadzein, and 
Canthine 6 one showed good binding affinity with both IL17a and IL18. Hence, these compounds can be analyzed by further in vitro studies and can be a lead in the designing of potential drug in the treatment of Gout disease.

\section{ACKNOWLEDGMENTS}

The author would like to thank the Vels Institute of Science Technology and Advanced Studies management for their support toward the successful completion of the research work.

\section{FINANCIAL SUPPORT}

None.

\section{CONFLICTS OF INTEREST}

The author declares no conflicts of interest.

\section{REFERENCES}

Adejoro IA, Waheed SO, Adeboye OO. Molecular docking studies of Lonchocarpus cyanescens triterpenoids as inhibitors for malaria. J Phys Chem Biophys, 2016; 6(2):1-4.

Afriza D, Suriyah WH, Ichwan SJ. In silico analysis of molecular interactions between the anti-apoptotic protein survivin and dentatin, nordentatin, and quercetin. J Phys Conf Ser, 2018; 1073(3):1-7.

Azam SS, Abbasi SW. Molecular docking studies for the identification of novel melatoninergic inhibitors for acetylserotoninO-methyltransferase using different docking routines. TBioMed, 2013; 10(1):1-16.

Bajpai VK, Alam MB, Quan KT, Ju MK, Majumder R, Shukla S, Huh YS, Na M, Lee SH, Han YK. Attenuation of inflammatory responses by $(+)$-syringaresinol via MAP-Kinase-mediated suppression of NF- $\mathrm{KB}$ signaling in vitro and in vivo. Sci Rep, 2018; 8(1):9216:1-10.

Cavalcanti NG, Marques CD, Lins e Lins TU, Pereira MC, Rêgo MJ, Duarte AL, Pitta ID, Pitta MG. Cytokine profile in gout: inflammation driven by IL-6 and IL-18? Immunol Invest, 2016; 45(5):383-95.

Chandrashekhar VM, Ganapaty S, Ramkishan A, Narsu ML. Neuroprotective activity of gossypin from Hibiscus vitifolius against global cerebral ischemia model in rats. Indian J Pharmacol, 2013; 45(6):575.

Cheng F, Li W, Zhou Y, Shen J, Wu Z, Liu G, Lee PW, Tang Y. admetSAR: a comprehensive source and free tool for assessment of chemical ADMET properties. J Chem Inf Model, 2012; 3099-105.

Chiu CC, Chen $\mathrm{CH}$, Huang MC, Chen PY, Tsai CJ, Lu ML. The relationship between serum uric acid concentration and metabolic syndrome in patients with schizophrenia or schizoaffective disorder, J Clin Psychopharmacol, 2012; 32(5):585-92.

Chung BH, Kim S, Kim JD, Lee JJ, Baek YY, Jeoung D, Lee H, Choe J, Ha KS, Won MH, Kwon YG. Syringaresinol causes vasorelaxation by elevating nitric oxide production through the phosphorylation and dimerization of endothelial nitric oxide synthase. Exp Mol Med, 2012; 44(3): 191 .

Dai J, Li N, Wang J, Schneider U. Fruitful decades for canthin-6ones from 1952 to 2015: biosynthesis, chemistry, and biological activities. Molecules, 2016; 21(4):493.

de Andrade JA, Gayer CR, de Almeida Nogueira NP, Paes MC, Bastos VL, Neto JD, Alves SC, Coelho RM, da Cunha MG, Gomes RN, Águila MB. The effect of thiamine deficiency on inflammation, oxidative stress and cellular migration in an experimental model of sepsis. J Inflamm, 2014; 11(1):11.

Doherty M. New insights into the epidemiology of gout. Rheumatology, 2009; 48:ii2-8.

Dundas J, Ouyang Z, Tseng J, Binkowski A, Turpaz Y, Liang J. CASTp: computed atlas of surface topography of proteins with structural and topographical mapping of functionally annotated residues. Nucleic Acids Res, 2006; 34(suppl_2):W116-8.

El Ridi R, Tallima H. Physiological functions and pathogenic potential of uric acid: a review. J Adv Res, 2017; 8(5):487-93.
Feig DI, Kang DH, Johnson RJ. Uric acid and cardiovascular risk. N Engl J Med, 2008; 359(17):1811-21.

Frieder J, Kivelevitch D, Menter A. Secukinumab: a review of the anti-IL-17A biologic for the treatment of psoriasis. Ther Adv Chronic Dis, 2018; 9(1):5-21.

Gerald F and Falasca MD. Metabolic diseases: gout. Clin. Dermatol, 2006; 24(6):498-508.

Gholijani N, Gharagozloo M, Farjadian S, Amirghofran Z. Modulatory effects of thymol and carvacrol on inflammatory transcription factors in lipopolysaccharide-treated macrophages. J Immunotoxicol, 2016; 13(2):157-6.

Grayson PC, Kim SY, LaValley M, Choi HK. Hyperuricemia and incident hypertension: a systematic review and meta-analysis. Arthritis Care Res (Hoboken), 2011; 63(1):102-10.

Huang YH, Rose PW, Hsu CN. Citing a data repository: a case study of the protein data bank. PloS one, 2015; 10(8):e0136631.

Karunakar P, Girija CR, Krishnamurthy V, Krishna V, Shivakumar KV. In silico antitubercular activity analysis of benzofuran and naphthofuran derivatives. Tuberc Res Treat, 2014; 2014:1-10.

Kemmish H, Fasnacht M, Yan L. Fully automated antibody structure prediction using BIOVIA tools: validation study. PLoS One, 2017 12(5):1-26.

Kim S, Thiessen PA, Bolton EE, Chen J, Fu G, Gindulyte A, Han L, He J, He S, Shoemaker BA, Wang J. PubChem substance and compound databases. Nucleic Acids Res, 2015; 44(D1):D1202-13.

Kirkham BW, Kavanaugh A, Reich K. Interleukin-17A: a unique pathway in immune-mediated diseases: psoriasis, psoriatic arthritis and rheumatoid arthritis. Immunology, 2014; 141(2):133-42.

Kostalova E, Pavelka K, Vlaskova H, Musalkova D, Stiburkova B. Hyperuricemia and gout due to deficiency of hypoxanthine-guanine phosphoribosyltransferase in female carriers: new insight to differential diagnosis. Clin Chim Acta, 2015; 440:214-7.

Lipinski CA, Lombardo F, Dominy BW, Feeney PJ. Experimental and computational approaches to estimate solubility and permeability in drug discovery and development settings. Adv Drug Deliver Rev, 2012; 64:4-17.

Liu Y, Zhao Q, Yin Y, McNutt MA, Zhang T, Cao Y. Serum levels of IL-17 are elevated in patients with acute gouty arthritis. Biochem Biophys Res Commun, 2018; 497(3):897-902.

Marashly ET, Bohlega SA. Riboflavin has neuroprotective potential: focus on Parkinson's disease and migraine. Front Neurol, 2017; $8: 333$

Meenambiga SS, Venkataraghavan R, Biswal RA. In silico analysis of plant phytochemicals against secreted aspartic proteinase enzyme of Candida albicans. J Appl Pharm Sci, 2018; 8(11):140-50.

Mohandas R, Johnson RJ. Uric acid levels increase risk for newonset kidney disease. J Am Soc Nephrol, 2008; 19(12):2251-3.

Morris GM, Goodsell DS, Halliday RS, Huey R, Hart WE, Belew RK, Olson AJ. Automated docking using a Lamarckian genetic algorithm and an empirical binding free energy function. J Comput Chem, 1998; 19(14):1639-62.

Morris GM, Huey R, Lindstrom W, Sanner MF, Belew RK, Goodsell DS, Olson AJ. AutoDock4 and AutoDockTools4: automated docking with selective receptor flexibility. J Comput Chem, 2009; 30(16):2785-91.

Naghdi Badi H, Abdollahi M, Mehrafarin A, Ghorbanpour M, Tolyat M, Qaderi A, Ghiaci Yekta M. An overview on two valuable natural and bioactive compounds, thymol and carvacrol, in medicinal plants. J Med Plant Res, 2017; 3(63):1-32.

Ragab G, Elshahaly M, Bardin T. Gout: an old disease in new perspective—a review. J Adv Res, 2017; 8(5):495-511.

Roddy E, Doherty M. Epidemiology of gout. Arthritis Res Ther, 2010; 12(223):1-11.

Saigal R, Agrawal A. Pathogenesis and clinical management of gouty arthritis. J Assoc Physicians India, 2015; 63:56-63.

Sedimbi SK, Hägglöf T, Karlsson MC. IL-18 in inflammatory and autoimmune disease. Cell Mol Life Sci, 2013; 70(24):4795-808. 
Shi LS, Wu CH, Yang TC, Yao CW, Lin HC, Chang WL. Cytotoxic effect of triterpenoids from the root bark of Hibiscus syriacus. Fitoterapia, 2014; 97:184-91.

Soltani Z, Rasheed K, Kapusta DR, Reisin E. Potential role of uric acid in metabolic syndrome, hypertension, kidney injury, and cardiovascular diseases: is it time for reappraisal? Curr Hypertens Rep, 2013; 15(3):175-81.

Soumyakrishnan S, Sudhandiran G. Daidzein attenuates inflammation and exhibits antifibrotic effect against Bleomycin-induced pulmonary fibrosis in Wistar rats. Biomed Prev Nutr, 2011; 1(4):236-44.

Sun MY, Ye Y, Xiao L, Rahman K, Xia W, Zhang H. Daidzein: a review of pharmacological effects. Afr J Tradit Complement Altern Med, 2016; 3(3):117-32.

Verdrengh M, Jonsson IM, Holmdahl R, Tarkowski A. Genistein as an anti-inflammatory agent. Inflamm Res, 2003; 52(8):341-6.

Yuan S, Chan HS, Hu Z. Using PyMOL as a platform for computational drug design. Wiley interdisciplinary reviews. Comput Mol Sci, 2017; 7(2):e1298.
Zhou Z, Li X, Li H, Guo M, Liu S, Li C. Genetic analysis of IL17 gene polymorphisms in gout in a male Chinese Han population. PLoS One, 2016; 11(2):e 0148082.

How to cite this article:

Hari S. In silico molecular docking and ADME/T analysis of plant compounds against IL17A and IL18 targets in gouty arthritis. J Appl Pharm Sci, 2019; 9(07):018-026. 